\title{
A Socratic lesson
}

\section{TRAJANO VIEIRA}

$\mathrm{M}$

OST OF us are familiar with the passage of the Phaedo in which Socrates explains to a surprised visitor the activity to which he devoted himself in prison during the days that preceded his death. The philosopher composed poetry, something curious considering his stubborn rejection of the literary genre. According to Socrates, he was obeying the urgings of a dream vision, which had come to him frequently in his life and bidden him, "O Socrates, compose and practice music!" (60e). He thus devoted his time to complying with the dream admonition, convinced that philosophy was the "supreme music." However, in prison he decided to compose poems as they were understood by most people (6la). The fact that he had endeavored in the past to "produce" abstract argument ("logos") rather than narrating "myths", which in his view would be the very base of poetic activity, led him to resort to Aesop's fables, which he knew by heart. So, just before swallowing the deadly draught, Socrates versified Aesop's prose.

The episode is indeed surprising. Music would structure rational and poetic thought. The specific organization of the world of music would be the foundation of abstract and concrete reasoning. Socrates, hitherto averse to mimetic language, devotes to it his last moments, not as a critic but as a poet. The philosopher realizes that the knowledge of this subtle expression depends on practice and not on analytical instruments. Whatever the interpretation of the passage in question, it will be difficult to ignore that in the throes of life, still intent on obeying his recurring dream, Socrates accepts that knowledge of poetry has to do with its practice and not with its exegesis.

Allow me to incur a sudden change of context before devoting a few lines to the issue of translation of Greek poetry among us. In an essay published in $1996^{1}$ George Steiner notes that there are more English translations of Homer than of the Bible. The essayist adds that soon after a Homeric edition has been published another is announced. This rich tradition is still alive thanks to the favorable reception that literary translations enjoy in American and English academia. Thanks also to the prevailing perception in some countries that there is no such thing as definitive translation. An interesting example is that of Christopher Logue. ${ }^{2}$ An English actor who appeared in James Bond movies, Logue has no knowledge of Greek and translates indirectly chants from the Iliad. He goes as far as writing in capital letters, in an emotional invocation, APOLLO! in the center of two pages. He makes use of colloquialisms and updates warlike instruments, which did not prevent Steiner from considering his work a "translation of genius". I also draw attention to the collection conceived by William Arrowsmith - a Hellenist who, besides a great translator of Aristophanes, also translated into English all of Montale's poems - called Greek Tragedy in new 
Translations, published by Oxford University Press. Each title brings together a poet and an expert who translated creatively, in teams, the tragic Greeks.

One of the obstacles to projects like that among us stems from the anti-Socratic attitude that prevailed for years in our academic milieu. We were and still are submissive to the philology of positivist bias. The encyclopedic erudition that permeates classical studies often acquires a tone of authority, as if there was ultimately a definitive version of the text, which the archaeological and methodical labor would be equipped to retrieve. It is not about disregarding the value of this tradition, but rather the professorial way in which it often tries to impose itself. Unlike Socrates, it rarely allows itself to creatively face the original text. Inhibited by the great work, it produces versions that aesthetically oscillate between doubtful and catastrophic, as if it were the custodian of the matrix. We are left with the impression that among us, with few exceptions, the translation of classical poetry exists as an appendix to academic reviews. The average reader is led to think that the original is that which the university translator renders in Portuguese. It is an illusion of literalness. One seeks to translate a poem word by word, rearranging the syntax when literal translation would become incomprehensible. There is no concern as to whether the result in the target language has aesthetic dimension, the secondary parameter for the "rigor" of scientific doctrine. One translates as if the resulting text were intended to serve as an exegetical platform. It would be interesting, in this case, to go back to the Socratic lesson.

Translation of poetry should be an act of courage and permanent risk rather than of shyness before the great work. The creative translator has no reason to fear error, which is secondary if his gesture has magnitude and sincerity. It is not the normative principles advocated by readers obsessed with papers that will enable us to assess whether a translation is good or bad. Hugh Kenner, in The Pound Era, analyses a beautiful translation that the author of the Chants rendered of a poem by Ibycus. $^{3}$ At the end Pound strays from the original, but the Ibycus that transpires in this passage is closer to the matrix than a literal translation could ever aspire to be.

This is not about defending the error, but about considering it secondary in the project that takes invention as the starting point. Similarly, given the nature of this type of production it would be wrong to defend a single principle for the creative translation of poetry. It will be up to each one to find and improve his technique in the path discovered. In my case, to be worthy of the invitation I have been honored with in the activity of Greek poetry translator, I wish to state upfront the importance of the years I spent with Haroldo de Campos, when I had the opportunity to follow and organize his translation of the Iliad. It was more than a decade of daily conversations which, although focused on Homer were far from being restricted to him. An attentive reading of the epic would soon lead to other works which Haroldo, endowed with great poetic memory, brought to light. He often faxed me the Greek text underlined and highlighting some formal relation. Paronomasias, unusual syntactic structures were aspects highlighted by the poet, to be re-imagined in Portuguese. Many pages of his manuscripts resem- 
ble imaginary maps, in which the space is occupied unpredictably: various colors of pens to highlight different aspects to be retrieved, arrows that lead the reader to the margins filled with comments, names, analogies, quotes, etc.

Clearly, this friendship has left marks on my work. Formal relations and intentional repetitions of classical authors are some of the aspects on which I try to focus. Aeschylus, in the oldest tragedy to come to us, The Persians, excels in the initial speech of the Coryphaeus: in a superbly high registers he inserts a list of Oriental names in the Greek metric structure. All the noble exuberance of the contingent led by Xerxes is initially marked by the redundant use of poli- ("many", "multi-"). Equally extraordinary is the repetition of words derived from the root meaning "gold." How not to be instigated by such formidable splendor and mysterious sonority? Allow me to mention the solutions I found in the work I have just completed, so that the reader can concretely assess a possible path for literary translation:

\author{
Corifeu: \\ ${ }^{\mathrm{TN}}$ Eis-nos remanescentes solitários \\ dos persas, hoje na Hélade. Fiéis \\ nos chamam, guardiões do paço pluridourado. \\ O basileu, o magno Xerxes, \\ estirpe de Dario, \\ nos incumbiu de vigiar aqui, \\ em reconhecimento às nossas cãs. \\ À espera de que volte o rei dos reis \\ à frente do tropel pluridourado, \\ o coração profético-soturno \\ se interna em aflição, \\ pois todo brio proveniente da Ásia \\ partiu e, ausente o homem, grunbe o cão \\ $<$ \\ Nenbum palafreneiro ou mensageiro \\ arriba neste burgo persa, Susa \\ deixada para trás, e Ecbatana \\ e o propugnáculo ancestral de Cission: \\ parte foi em navio, parte a cavalo, \\ a maioria a pé para compor \\ o aglomerado marcial. Amistres \\ partiu, partiu Artáfrenes, além \\ de Megabates, junto com Astaspes, \\ os lideres dos persas, \\ vassalos basileus do Basileu,
}


inquietos, entestando pluriexércitos,

os magniarqueiros, ases montadores, tétricos de avistar, horror no prélio

pelo impeto empenbado.

Mais Artembaris, hipicopugnaz,

e Masistrés e Imeu, um magniarqueiro

impoluto, Farándaques também,

Sostanes, condutor de seus corcéis.

Plurinutriz, o enorme Nilo envia

Susíscanes, Pegástagon, originário

do Egito, além do arconte mor da imácula

Menfis, Arsames com Ariomardo, imperador do mitico rincão

de Tebas, que desbravam os paludes

no delta, embasbacantes remadores

de embarcações, difíceis de contar,

chusma infinita engrossando o grupo.

E os lidios de viver efeminado

acorrem copiosos: todos cedem

a seu comando continente adentro,

regidos por Metrógates e Arcteu

imáculo. E os sardos aurimúltiplos

galopam encimando muitos carros

enfileirados dupla ou triplamente,

aparição apavorante à turba.

Another author who has been poetically properly translated into Portuguese is Aristophanes, the first vanguard writer in the Western world. In the parabasis of the Clouds, an episode in which the poet speaks directly to the audience in a serious tone, one reads (v.547): "I always act the sophist and introduce new ideas (kainas ideas)." In the Wasps, the spokesman of the chorus criticizes the negative reception of the Clouds because its author (i.e., Aristophanes himself...) disseminated "extremely innovative conceptions" (kainotatas... dianoias, v.1044). A central point in the poetry of Aristophanes is precisely the verbal quest. The plastic potential of the word, its expressive power, the unprecedented nature of constructions surprise even readers familiar with his work. As we read in the comedy the Frogs, the first work of literary criticism that reached us, the formal issue instigated Aristophanes. The dispute over who is the best poet, Aeschylus or Euripides, central in the second part of the play, follows two directions: ethics (which tragedy author made citizens betters) 
and aesthetics. Colloquial register versus heroic tone; expressive clarity versus imagetic refinement; invention or not of vocabulary compounds; introduction or not of philosophical and scientific jargons are some of the topics discussed. Aeschylus was the writer of the "old times" (ta palaia, 1107), whereas Euripides would pursue "originality" (ta kaina). The first would build diction as a tower (1004), while the second would divest the tragedy of its grandeur (1494-5).

To conclude, I would like to mention a sensitive Hellenist, open to comparisons between ancient Greek literature and modern production, W. B. Stanford. In his edition of the Frogs ${ }^{4}$ he draws attention to the similarity between Lewis Carroll's jabberwocky and the four symmetric stanzas of the Frogs (vv.814-29), prior to the dispute between Aeschylus and Euripides, which I translated as follows:

Coro:

TN $O$ altitonante vai enverdecer de raiva ao ver o dente acriloquaz que o contrartista

afila. Então a insânia apavorante

revira a órbita da vista.

E o palavreado criniequino do elmoaltivo enfrentará sutis aparas, que cinzelam feitos e fatos, quando o berói refugue charlas que o fabrocuca trota.

Hirto na nuca o velo criniveludoso, franze de sanha o cenbo, ruge e arroja termos que cavilha, siroco de titã avesso às tábuas do navio.

E a boquiturga verbialgoz do versocrata gasto espirala invidias e remove a brida, falaz multifocal sutilfatal à pena plena dos pulmões.

I believe that the translator of classical poetry should not bow to the glacial circumspection of philology. It is not difficult to venture into the scholarly flow that exegesis has been building over time. The issue lies in being able to distinguish between what results from penetrating reading and what stems from the routine practice of curricular imposition. 


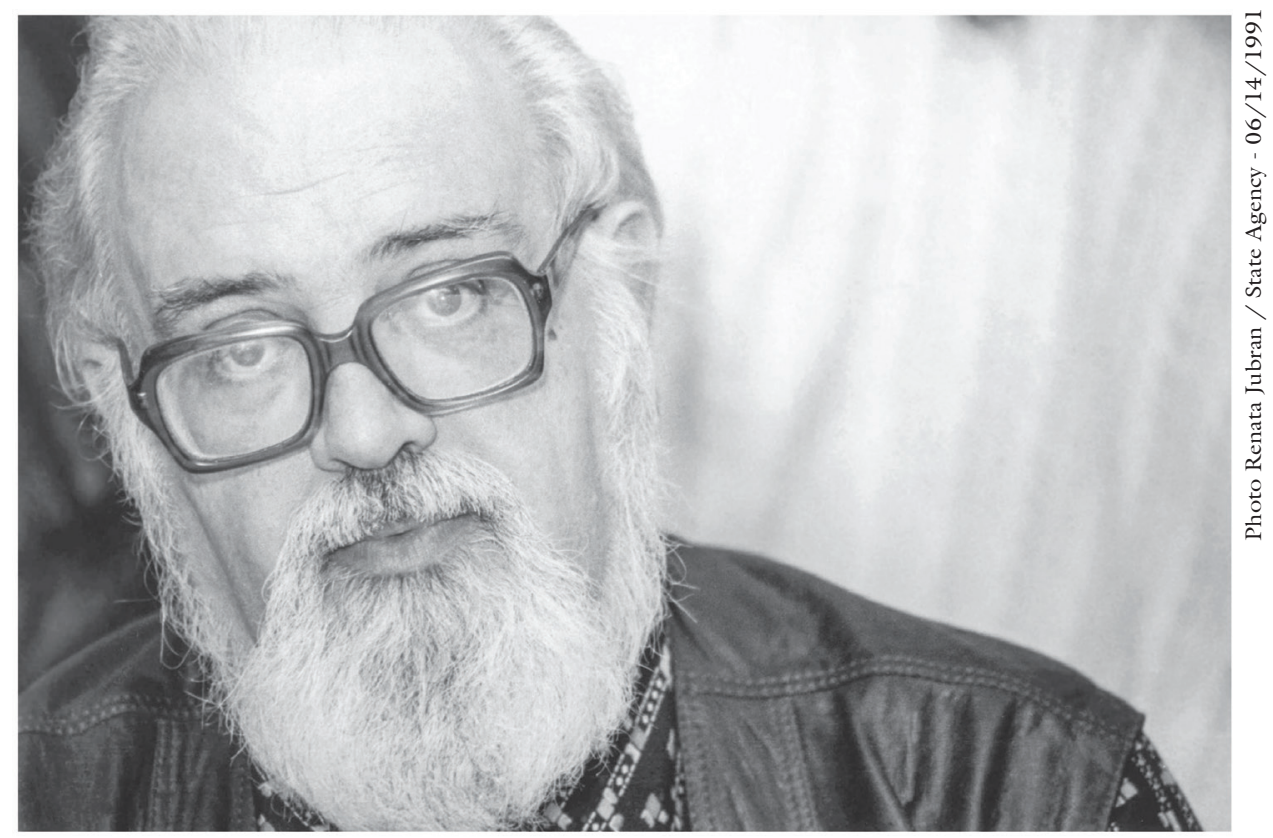

Haroldo de Campos (1929-2003).

Focusing more on the original texts and less on minor issues entangled in footnotes, learning to recognize meaningful novelty and permanently exercising compositional techniques are some of the parameters that I have sought to adopt in my professional life, with the aim of contributing to make the reading of Greek poetry less painful among us.

Notes

1 "Homer in English", included in No Passion Spent-essays 1978-1996, Faber and Faber, 1996.

2 War Music, The Noonday Press, 1997.

3 The Pound Era, University of California Press, 1971, p.138-42.

4 Frogs, Bristol Classical Press, 1958, p.XXXV.

TN The Persians (translated by Gilbert Murray)

Faithful to them that sailed o'ersea

To Grecian lands our name we hold,

"The Persians' Trust"; true guardians we

Of many a temple rich in gold

And holy, whom our Lord and King,

Xerxes, Darius-born,

For age and honour hath extolled

To watch his land forlorn.

And while we wait his homecoming, 
For him and for his golden host With fear and dark imagining My spirit in a storm is tossed. For all the strength of Asia born, Like hounds at a young master's horn Baying, away hath flown, And now for long no royal post Cometh, no rider from the host, Back to great Persia's Throne. From Agbatan, from Susa tall, From ancient Kissia's guarded wall, We saw the horse and chariot go, The gliding ships, the footmen slow, In pomp of war far-thrown. Among them men of mighty name, Amistras, Artaphernes, came, Astaspes, Megabâtes, Lords Of Persia, kings beneath the Eye Of the one King, most great, most high, Ruling their subject hordes, With trampling horse, with clanging bow, Dread to behold and stern to know, High hearts and faithful swords. Then Artembar, glad knight in fray, Imaios of the shafts that slay, Masistras, Pharandâkes, yea, And charioted Sosthânes Rode past us. Many another king Did Nile the many-childed bring, To war; the Master of the Spring, Egyptian Sousiskânes, Arsam the tall, who holdeth guard O'er holy Memphis, Ariomard From ageless Thebes, with river men Who bend the bow and stride the fen, Multitudes dark and fell.

We saw the armies proud and gay Of Lydia, who in thralldom sway The tribes of Asia; them the wise Arcteus and Mêtrogâthes, Eyes Of the Great King, from Sardis sent With all her golden armament: In fourfold aye and sixfold team We saw their myriad chariots gleam, Fearful to see or tell.

TN The Frogs (translated by Matthew Dillon) 


\section{Chorus:}

Surely the dreadful thunderer will feel wrath within him as he looks at the rival whetting his babbling tusk.

Then his eyes will spin with awful madness.

There will be the helmet-blazing strife of horse-crested phrases;

Axle-splinterings as the chisel-working fellow defends himself against the horse-galloping utterances of the mind-building man.

Bristling the shaggy-necked mane of his natural-hair crest, Knitting his terrible brow, bellowing, he will launch bolt-fastened utterances, ripping them apart board by board with gigantic blast of breath.

Then the mouth-worker, tester of phrases, smooth tongue, unfurling, stirring the reins of envy, dissecting the utterances, will quibble away the great labor of his lungs.

ABSTRACT - Philological translations of Greek poetic works often overlook key aspects of literary expression. This stems from the delusion of literalness: it is believed that rigorous, literal translation is able to capture the essence of the original. This procedure ignores what actually constitutes a poetic work: its rhythm, its form, its figures of speech, its melopoeia. Generally, none of these aspects are reworked in the target language by academic Hellenists, who seem to view translation as a mere framework for their comments. We must consider poetic translation from another angle. Re-imagining the formal elements is a challenge that must be faced out of respect for readers who don't have access to the original poem. The awareness that is impossible to fully retrieve the formal dimension of the text should not discourage a translator sensitive to poetic expression. In this case, a resolute bias is worth more than the illusion of totality.

KEYWORDS: Translation, Poetic translation, Greek literature.

Trajano Vieira is a Professor of Greek Language and Literature at the State University of Campinas (Unicamp). He is the author of Édipo Rei de Sófocles (Perspectiva, 2001); Electra(s) (Ateliê, 2009); Odisseia (Ed. 34, 2011), among other books.

@ - trajanovieira@uol.com.br

Received on 6 Aug. 2012 and accepted on 20 Aug. 2012. 